\title{
Pharmacognostical and Phytochemical Analysis of Vanya Haridra (Curcuma Aromatica Salisb.) Rhizomes
}

\author{
${ }^{1}$ Debbarma Promod, ${ }^{2}$ Kato Tatak Anu, ${ }^{3}$ Jaiswal Mohanlal \\ ${ }^{1,2}$ P.G. Scholar, Deptt. of Dravyaguna Vigyan, National Institute of Ayurveda, Jaipur \\ ${ }^{3}$ Professor, Deptt. of Dravyaguna Vigyan, National Institute of Ayurveda, Jaipur \\ Corresponding Author:- Dr.Promod Debbarma \\ ${ }^{1}$ P.G. Scholar, Deptt. of Dravyaguna Vigyan, National Institute of Ayurveda, Jaipur
}

\begin{abstract}
:
Vanya Haridra (Curcuma aromatic Salisb.)also known as Aranya Haridra in Sanskrit, very important plant in use since long decade in traditional medicine in India. It is known as wild turmeric in English/cochin turmeric, van haldi in hindi, anakuva in Malayalam, kasturi manjal in tamil. It is mentioned as kusthaghna, arshaghna properties in Bhavaprakas Nighantu, Throughout the India, specially found in Mysore, Cochin and Bengal etc, rootstock large of palemately branched, sessile annulated biennial tubers yellow and aromatic inside, hairy and masked with circular disk. It is camphoraceous and jambula like fragrant odour. On these ground, this work was attempt to establish pharmacognostical and preliminary phytochemical standard of rhizomes, pharmacognostical parameters using like macromorphology, microcopy, physiochemical constant and phytochemical analysis were done using standard methodology. It showed presence of carbohydrate, alkaloids, amino acids, protein, saponin, glycosides, flavonoids, steroids and tannins in aqueous, ethanol and petroleum ether extract.
\end{abstract}

Keywords: Vanya Haridra (Curcuma aromatica Salisb.), Pharmacognostical, Phytochemicals in aqueous, ethanoland petroleum Ether extracts.

\section{Introduction}

Curcuma aromatica Salisb is a medicinally important species belonging to the family Zingiberaceae. It is occurring wild throughout India and cultivated chiefly in West Bengal and Travancore. The plant is commonly known as Junglee Haldi (wild turmeric). The historical evidence of Vanya Haridra is not found in Vedic period, Samhita period, Anciant Nighantu period, except Bhavaprakash Nighantu and modern text. Bhavmishra described in Bhavaprakash Nighantu of Vanya Haridra about Vernacular Name, Morphological brief description, Properties and therapeutic used. ${ }^{1}$

\section{Taxonomical classification of Vanya Haridra ${ }^{2,3}$}

Division- Spermatophyta

Sub-division- Angiospermae

Class- Monocotyledonae

Series- Epigynae

Family- Zingiberaceae 
${ }^{1}$ Debbarma Promod , International Journal of Ayurvedic\& Herbal Medicine 8(3) May.-June. 2018 (3212-3222)

Genus- Curcuma

Species - aromatica Salisb

Latin Name - Curcuma aromatica Salisb.

\section{Vernacular Name:}

Sans - Aranya Haridra.

Beng - Van Halodi, Van Halud

Hindi- Jangali Haladi, Van Haridra.

Mar- Vedi-Haldi, Amba Haldi.

Malayalam - Anakuva.Tamil-Kasturi manjal.

Tel - Kattu manal.

Eng - Wild Turmeric, Cochin Turmeric.

\section{Botanical description:}

Distribution- throughout the India, specially found in Mysore, Cochin and Bengal etc. Characters- Root stock large of palemately branched, sessile annulate beinnial tubers yellow and aromatic inside, hairy and masked with circular disk. It a camphoraceous and jambula like fragrant odour.Leaves-38-60 by $10-20 \mathrm{~cm}$, oblong lanceolate, green often variegated above pubescent beneath, base deltoid. Flower- flowering stem appearing with or the leafing stem, flowers fragrant, shorter then the bracts, in spikes 15-30 cm. long. Calyx- $8 \mathrm{~mm}$ long, irregularly 3 lobed. Corolla tube $2.5 \mathrm{~cm}$ long, the upper half funnel shaped, lobess pale rose-coloured, Lip yellow. ${ }^{4,5}$

Chemical constituents-Rhizomes yield $6.1 \%$ essential oil (Chopra et al, 1980). Essential oil contains $\alpha$-and - $\beta$-curcumene, $d$-camphene and p-methoxy cinnamic acid. The colouring matter is curcumin. Numerous sesquiterpenoids of germacrone and guaiane skeletons have been identified recently (Husain et al, 1992). C. aromatica rhizomes contain ar-curcumene (18.6\%), beta curcumene (25.5\%) and xanthorhizol $(25.7 \%)$ (Zwaving and Bos, 1992). The active constituents of oil are curcumol and curdione (Asolkar et al, 1992). Structures of sesquiterpenes were studied by Kuroyanagi et al (1990). Its rhizome is a rich source of volatile oil, which consists of several major anti-tumor ingredients including demethoxycurcumin, $\beta$-elemene, curcumol, curdione, etc. It is used as anti-venom for Indian cobra, used as tonic, to treat digestive problems 6,7

\section{Material and Methods:}

Collection of Plant Materials-Vanya harirda plants were collected from Palakkad district, kerala, in the month of February 2017. Specimens were dried by keeping them between the folds of old newspapers. It is necessary to change these papers at regular intervals, until the plants are well dried.The dried specimens were pasted on the herbarium sheets of standard size with proper labeling. The authentication of plants material collected for study was done at Herbarium section, Botany department, University of Tripura, Suryamaninagar-799022, Tripura State, with Authentification Accession No.1664 as Curcuma aromatic salisb. and belong to family Zingiberaceae by Dr.B. K. Datta (Professor of Botany).After identifying the plant, for study purpose rhizomes of Vanya Haridra is washed with running water and kept for drying under shade.The procured dried parts werepowdered,abeled, packed and subjected for organoleptic and other analytic studies.

\section{Pharmacognostic Study:}

Pharmacognostic study was carried on the basis of Morphological characters such as colour, odour, taste, size, fracture etc 
${ }^{1}$ Debbarma Promod , International Journal of Ayurvedic\& Herbal Medicine 8(3) May.-June. 2018 (3212-3222)

\section{Physiochemical Parameters:}

\section{Determination of moisture content ${ }^{8}$}

Moisture content was determined by placing weighed sample of $5 \mathrm{gm}$ of drug in oven at $105^{\circ}$ for 5 hours, and calculate weight of sample for every 30 minute, until the weight of the sample were constant, no variation of weight are recorded. This sample was allowed to cool at room temperature in desiccators for 1 hour before weighing.

\section{Determination of Ash Value ${ }^{9}$}

Total Ash Value- Weighed accurately $2 \mathrm{~g}$ of the air-dried drug (rhizome) in a silica dish and incinerated at a temperature not exceeding $450^{\circ}$ until free from carbon. Then cool and weighed. Percentage of ash value was calculated on the the basis of airdried drug.

Acid Insoluble Ash- Boiled the ash with $25 \mathrm{ml}$ of $2 \mathrm{M}$ hydrochloric acid for 5 minutes, collected the insoluble matter in a Gooch crucible, washed with hot water, ignited, cooled in a desiccator and weighed. Calculated the percentage of acid-insoluble ash on the air dried drug basis.

Water Soluble Ash- Boiled the ash for 5 minutes with $25 \mathrm{ml}$ of water, collected the insoluble matter in a Gooch crucible, washed with hot water, and ignited for 15 minutes at a temperature not exceeding $450^{\circ}$. Subtracted the weight of the insoluble matter from the weight of the ash; the difference in weight represents the water-soluble ash. Percentage of water soluble ash was calculated with reference to the air dried drug.

\section{Extractive value: ${ }^{10}$}

Water Soluble Extractive Value: Macerate $5 \mathrm{gm}$ of the air dried drug, coarsely powdered of Curcuma aromatic Salisb, with $100 \mathrm{ml}$ ofwater of the specified strength in a closed flask for twenty-four hours, shaking frequently during six hours and allowing to stand for eighteen hours. Filter rapidly, taking precautions against loss of solvent, evaporate $25 \mathrm{ml}$ of the filtrate to dryness in a tared flat bottomed shallow dish, and dry at $105^{\circ}$, to constant weight and weigh. Calculate the percentage of water-soluble extractive with reference to the air-dried drug.

Alcohol Soluble Extractive value: Macerate $5 \mathrm{~g}$ of the air dried drug, coarsely powdered, with $100 \mathrm{ml}$ of Alcohol of the specified strength in a closed flask for twenty-four hours, shaking frequently during six hours and allowing to stand for eighteen hours. Filter rapidly, taking precautions against loss of solvent, evaporate $25 \mathrm{ml}$ of the filtrate to dryness in a tared flat bottomed shallow dish, and dry at $105^{\circ}$, to constant weight and weigh. Calculate the percentage of alcohol-soluble extractive with reference to the air-dried drug.

Petroleum Ether Soluble Extractive value (Fixed Oil Content)- ${ }^{4}$ Transfer a suitably weighed quantity (depending on the fixed oil content) of the air dried, crushed drug to an extraction thimble, extract with Solvent ( petroleum ether, b.p. $40^{\circ}$ to $60^{\circ}$ ) in a continuous extraction apparatus (Soxhlet extractor) for 6 hours. Filter the extract quantitatively into a tared evaporating dish and evaporate off the solvent on a water bath. Dry the residue at $105^{\circ}$ to constant weight. Calculate the percentage of Petroleum Ether-soluble extractive with reference to the air-dried drug.

\section{Preliminary Phytochemical Screening ${ }^{11}$}

Phytochemical examinations were carried out for all the extracts as per the standard methods.

\section{Tests for Carbohydrates}

Molisch's Test- $2 \mathrm{ml}$ of test Solution was taken in a test tube and $2 \mathrm{ml}$ of the Molisch's reagent(Dissolve $10 \mathrm{gm}$ of $\alpha$-napthol in $100 \mathrm{ml}$ of $95 \%$ alcohol ) was added and shaken carefully and then about $1 \mathrm{ml}$. of conc. $\mathrm{H}_{2} \mathrm{SO}_{4}$ is poured from side of the test tube and allowed to stand for one 1 minute. A Purple colour ring at the junction of the two layers if formed indicated the presence of Carbohydrate.

\section{Test for reducing sugars:}

Benedict's test -It is used for reducing sugars and composed of mainly Copper sulphate and sodium hydroxide. Mix equal volume of Benedict's reagent and test solution in test tube. Heat in boiling water bath 
${ }^{1}$ Debbarma Promod , International Journal of Ayurvedic\& Herbal Medicine 8(3) May.-June. 2018 (3212-3222)

for 5 minutes. Solution appears green, yellow, orange, red or brown colour depending on amount of reducing sugar present in test solution.

Fehling solution test-It is generally used for reducing sugars and composed of two solutions, which are mixed in situ. Fehling solution A composed of $0.5 \%$ of copper sulphate whereas Fehling solution B composed of Sodium Potassium Tartarate. Equal volumes of Fehling A and Fehling B solutions were mixed ( $1 \mathrm{ml}$ each), boil for 1 minute.Add $2 \mathrm{ml}$ of aqueous solution of drug followed by boiling for 5-10 minutes on water bath. Formation of reddish brown coloured precipitate due to formation of Cuprous oxide indicates presence of reducing sugar.

\section{Tests for Alkaloids}

Mayer's reagent test- $2 \mathrm{ml}$ of test Solution was taken in a test tube and $2 \mathrm{ml}$ of the Mayer's reagent (Potassium Mercury Iodide solution) was added. A White or Pale Yellow precipitate if formed indicated presence of Alkaloids except with Alkaloids of the Purine groups and few others.

Dragondroff's reagent test- $2 \mathrm{ml}$ of test Solution was taken in a test tube and $2 \mathrm{ml}$ of the Dragon Droff's reagent (Mixture of Potassium Iodide and Bismuth sub nitrate solution) was added. An orange precipitate if formed indicated presence of Alkaloids.

Wagner's test- Drug solution + few drops of Wagner's reagent (dilute Iodine solution), formulation of reddish-brown precipitate.

Hager's Test- A saturated aqueous solution of picric acid was employed for this test. When the test filtrate was treated with Hager's reagent, an orange yellow precipitate was obtained which indicates the presence of alkaloids.

\section{Test for Amino acids}

Ninhydrin test -The Ninhydrin test is used to detect the presence of alpha-amino acids and proteins containing free amino groups. Protein solution when heated with ninhydrin molecules, it gives characteristic deep blue or pale yellow colour due to formation of complex between two ninhydrin molecule and nitrogen of free amino acid.

\section{Test for proteins}

Xanthoprotein test- A small quantity of test sample was taken with $2 \mathrm{ml}$ of water and $0.5 \mathrm{ml}$ of concentrated nitric acid was added to it. Development of yellow colour indicates the presence of proteins.

Millon's test- The Millon reagent is a solution of mercuric and mercurous ions in nitric and nitrous acids. Take $1 \mathrm{ml}$ of sample solution in a test tube and add few drops of Millons reagent. White precipitate is produced, which turns red after heating for 5 minutes on water bath.

Biuret test (General test)- Take $1 \mathrm{ml}$ of sample solution in a test tube and add $2 \mathrm{ml}$ of $10 \% \mathrm{NaOH}$ solution followed by few drops of lead acetate solution. Shake the solution and boil on water bath for few minutes it produces black precipitate in presence of sulphur containing amino acids.

\section{Tests for Glycosides}

Borntragor's Test- $1 \mathrm{ml}$ of Benzene and $0.5 \mathrm{ml}$ of dilute ammonia solution was added to the extract and was observed for the formation of reddish pink colour.

\section{Test for Phenolic Compound}

The extract was taken in water and warmed; to this $2 \mathrm{ml}$ of ferric chloride solution was added and observed for the formation of green and blue colour.

\section{Test for Saponin}

Foam test-About $1 \mathrm{ml}$ of Aqueous Extract was diluted by distilled Water up to $10 \mathrm{ml}$ and shaken in a graduated cylinder for 15 minutes. Formation of $1 \mathrm{~cm}$ layer of froth indicates presence of Saponin.

\section{Test for Flavonoids}


${ }^{1}$ Debbarma Promod , International Journal of Ayurvedic\& Herbal Medicine 8(3) May.-June. 2018 (3212-3222)

Shinods test- A small quantity of test sample was dissolved in $5 \mathrm{ml}$ ethanol (95\% v/v) and reacted with few drops of concentrated hydrochloric acid and $0.5 \mathrm{gm}$ of magnesium metal. Appearance of pink, crimson or magenta colour within a minute or two indicate the presence of flavonoids.

Test for Steriods

Salkowaskireaction- Few $\mathrm{mg}$ of extract was taken in $2 \mathrm{ml}$ of chloroform and $2 \mathrm{ml}$ of concentrated sulphuric acid was added from the side of test tube. The test tube was shaken for few minutes. The development of red colour indicates the presence of sterols.

\section{Test for Tannins}

Fecl $_{3}$-A 5 percent solution of ferric chloride in $90 \%$ alcohol was prepared. Few drops of this solution were added to a little of the above filtrate. Appearance of dark green or deep blue colour indicates the presence of tannins.

Lead acetate - A 10 percent w/v solution of basic lead acetate in distilled water was added to the test filtrate. Development of precipitate indicates the presence of tannins.

Pot. Dichromate - A solution of potassium dichromate was added to the filtrate. Appearance of dark colour indicates the presence of tannins.

\section{Thin layer Chromatography: ${ }^{12}$}

Chromatography plates-T.L.C. plate coated with $0.25 \mathrm{~mm}$ layer of silica gel $60 \mathrm{~F}_{254}$ with fluorescent indicator, (Mercks) were used.

Activation of pre-coated Silica gel $\mathrm{G} 60 \mathrm{~F}_{254}$

Driedin hot oven at $105^{\circ} \mathrm{C}$ for one to two hour.

Preparation of mobile solution- Toluene: Ethyl acetate (9:1)

\section{Results and Discussion:}

\section{Pharmacognostic Study:}

Macroscopical examination of fresh rhizome-Size, shape \& structure-Rhizomes are $6.5-7 \mathrm{~cm}$ in length and 1.5-2 cm in diameter, less leteral branches, palmately attached and root tubers present.

Colour-Light yellow inside.

Odor-Sweet camphooraceous.

Taste- Pungent.

Touch-Slightly rough external surface with big round scar, hard \& heavy.

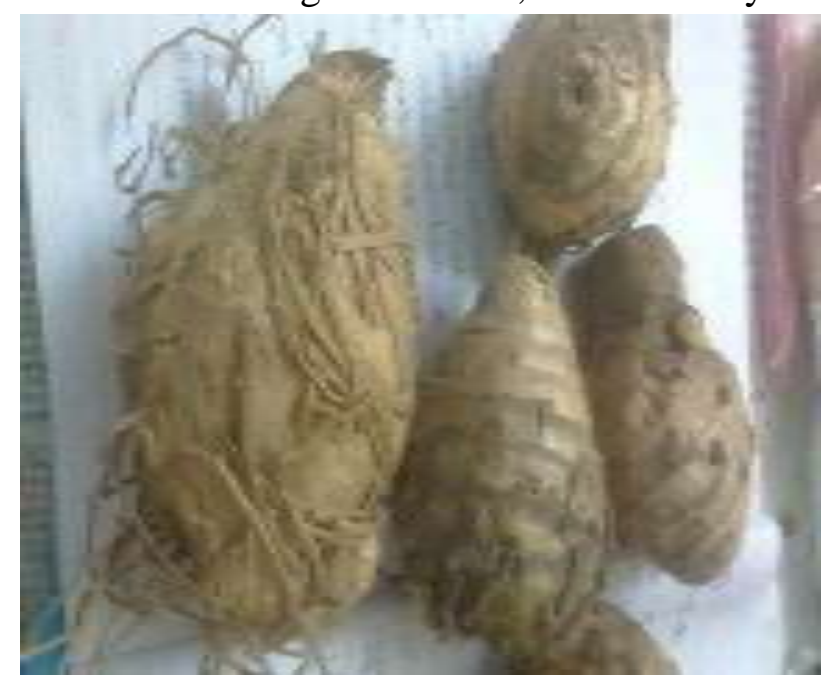

Figure:1. fresh rhizomes of Curcuma aromatica Salisb. 
${ }^{1}$ Debbarma Promod , International Journal of Ayurvedic\& Herbal Medicine 8(3) May.-June. 2018 (3212-3222)

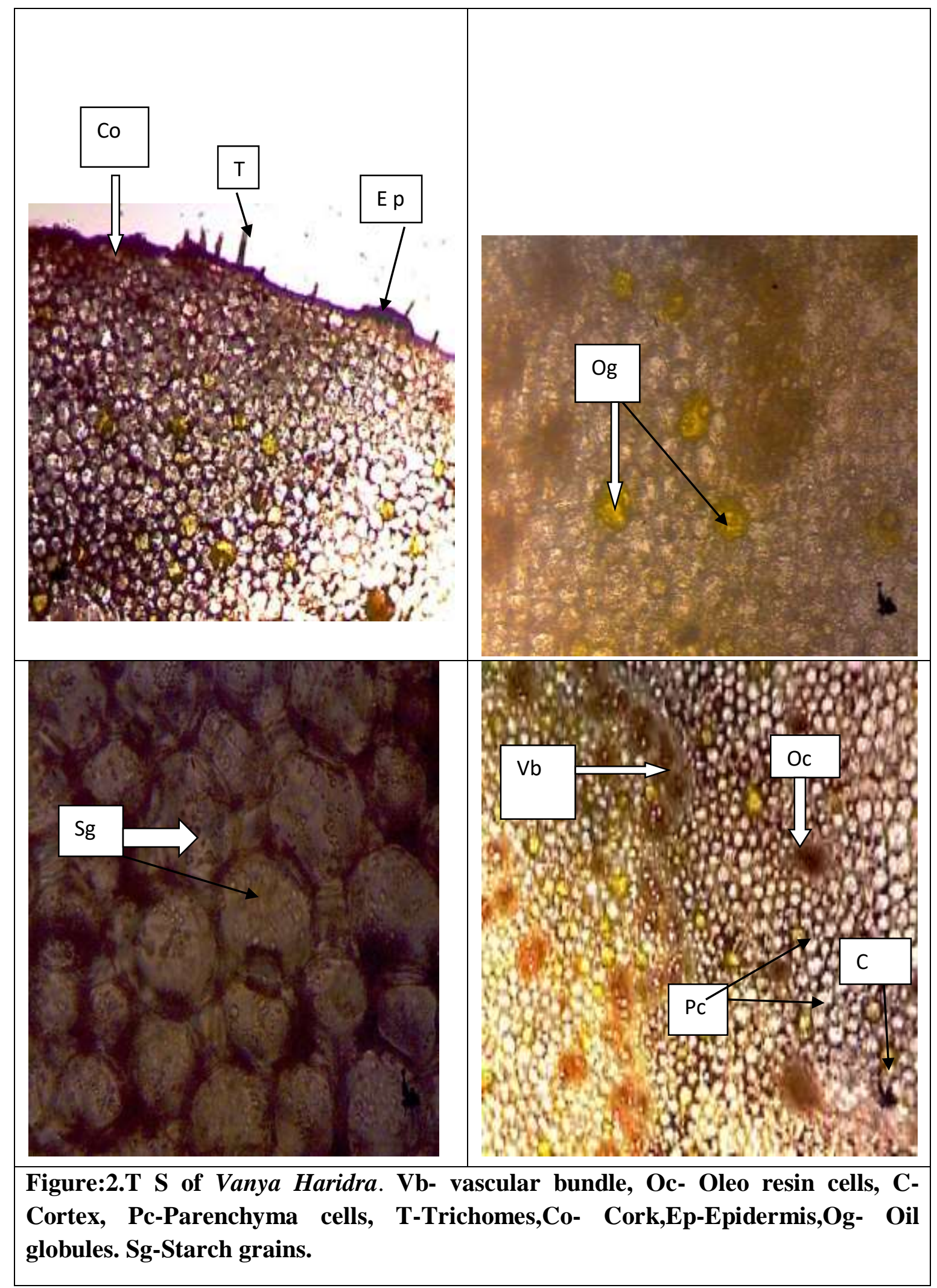

\section{Microscopic characters fresh rhizome of Vanya Haridra}

Epidermal hairs: 1-2 celled, branched, thick walled, lignified. Periderm - 3-5 layered.Outer cortex-Lesser number of scattered collateral vascular bundles, starch grains present.Inner cortex- Amphicribal vascular bundles arranged in patches.Vascular elements-Trachieds with spiral and scalary and vessels with reticulate thickening, bundle sheath absent, fibre present very few.Oil cells- Present. 
${ }^{1}$ Debbarma Promod , International Journal of Ayurvedic\& Herbal Medicine 8(3) May.-June. 2018 (3212-3222)

\section{Powder microscopic study of Vanya Haridra:}

In Powder microscopylignin, Cork, crystalloids, Starchgrains, Mucilage, lignified fibres, epidermal cells, were also seen in powder microscopy.

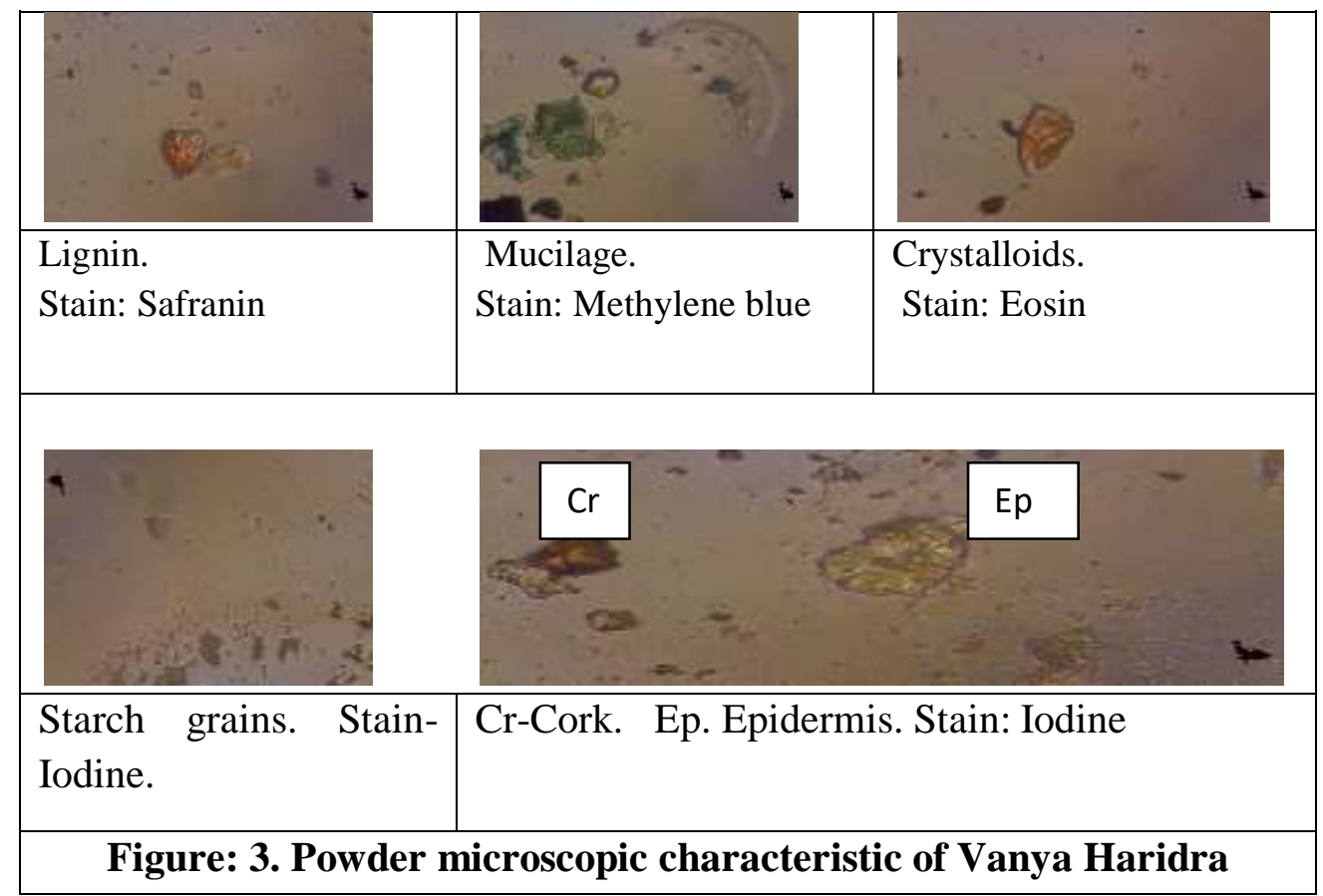

\section{Physicochemical parameters:}

In this study moisture content, ash values (total ash, acid insoluble ash and water soluble ash), extractive value (water soluble extractive value, alcohol soluble extractive value andPetroleum Ether Soluble Extractive value ) were determined below-

Moisture Content $4.35 \%$ w/w

Total Ash value- $3.114 \% \mathrm{w} / \mathrm{w}$

Acid Insoluble Ash $0.807 \%$ w/w

Water Soluble Ash $0.0411 \% \mathrm{w} / \mathrm{w}$

Water Soluble Extractive Value $1.648 \% \mathrm{w} / \mathrm{w}$

Alcohol Soluble Extractive Value $8.954 \% \mathrm{w} / \mathrm{w}$

Petroleum Ether Soluble Extractive value $1.044 \% \mathrm{w} / \mathrm{w}$

\section{Phytochemical analysis:}

Phytochemicalare nutritive plant chemicals that have protective or disease preventive properties.A plant cell produces two types of metabolites primary metabolites involved directly in growth and metabolism (carbohydrates, lipids and proteins etc), and secondary metabolites not involved in metabolic activity (alkaloids, phenolics, sterols etc) but act as defense chemicals. The Preliminary Phytochemical Investigations of Aqueous, Ethanolic and Petroleum Ether extract of rhizome Curcuma aromatica Salisb were preformed which reveals the presence of Carbohydrates, Alkaloids, Amino acids, Saponin, Glycosides, Flavonoids,Steroids and Tannins. The results of the screening were expressed in Table no. 1 
${ }^{1}$ Debbarma Promod , International Journal of Ayurvedic\& Herbal Medicine 8(3) May.-June. 2018 (3212-3222)

Table: 1. showing Phytochemical analysis

Carbohydrate test

\section{Alkaloids}

\begin{tabular}{|l|l|l|l|}
\hline Name of test & $\begin{array}{l}\text { Aquous } \\
\text { extract }\end{array}$ & $\begin{array}{l}\text { Ethanol } \\
\text { Extract }\end{array}$ & $\begin{array}{l}\text { Petroleum } \\
\text { Ether extract }\end{array}$ \\
\hline Malish test & $+\mathrm{ve}$ & $+\mathrm{ve}$ & $+\mathrm{ve}$ \\
\hline Benedict test & $+\mathrm{ve}$ & $+\mathrm{ve}$ & $-\mathrm{ve}$ \\
\hline Feling test & $+\mathrm{ve}$ & $+\mathrm{ve}$ & $+\mathrm{ve}$ \\
\hline Barfoad test & $+\mathrm{ve}$ & $+\mathrm{ve}$ & $+\mathrm{ve}$ \\
\hline
\end{tabular}

\begin{tabular}{|l|l|l|l|}
\hline Dragan drof & +ve & +ve & $+v e$ \\
\hline Wagner's test & + ve & -ve & -ve \\
\hline Mayer's test & +ve & +ve & $+v e$ \\
\hline Hager's test & +ve & +ve & -ve \\
\hline
\end{tabular}

\section{Amino acids}

\begin{tabular}{|l|l|l|l|}
\hline Ninhydrine & -ve & -ve & -ve \\
\hline Xanthoprotic & $+\mathrm{ve}$ & $+\mathrm{ve}$ & $-\mathrm{ve}$ \\
\hline
\end{tabular}

\section{Protein}

\begin{tabular}{|l|l|l|l|}
\hline Millon' test & -ve & -ve & -ve \\
\hline Biuret test & -ve & -ve & -ve \\
\hline
\end{tabular}

Saponin

\begin{tabular}{|l|l|l|l|}
\hline Foam test & -ve & -ve & +ve \\
\hline
\end{tabular}

\section{Glycosides}

\begin{tabular}{|l|l|l|l|}
\hline Killar kilini test & +ve & +ve & +ve \\
\hline Borntrager's test & +ve & $+\mathrm{ve}$ & $+\mathrm{ve}$ \\
\hline
\end{tabular}

\section{Phenolic compound}

\begin{tabular}{|l|l|l|l|}
\hline Phenolic test & -ve & -ve & -ve \\
\hline
\end{tabular}

\section{Flavonoids}

\begin{tabular}{|l|l|l|l|}
\hline Shinod's test & +ve & +ve & +ve \\
\hline
\end{tabular}

\section{Steroids}

\begin{tabular}{|l|l|l|l|}
\hline Salkowaski test & +ve & +ve & +ve \\
\hline
\end{tabular}

\section{Tannins}

\begin{tabular}{|l|l|l|l|}
\hline $\mathrm{Fecl}_{3}$ test & +ve & +ve & -ve \\
\hline Lead acetade test & +ve & +ve & -ve \\
\hline Pot.dichromate test & +ve & +ve & -ve \\
\hline
\end{tabular}


${ }^{1}$ Debbarma Promod , International Journal of Ayurvedic\& Herbal Medicine 8(3) May.-June. 2018 (3212-3222)

\section{Thin layer chromatography:}

Thin layer Chromatography is a tool for separation and identification of chemical constituentspresent in the herbs or chemical mixtures with mobile solution of Toluene: Ethyl acetate 9:1 ratio. Ethanolic extract of rhizomes of Vanya Haridra $\mathrm{R}_{\mathrm{f}}$ values $0.08,0.2,0.25,0.31,1.03$ in day light. $\mathrm{R}_{\mathrm{f}}$ values $0.15,0.23,0.24,0.25$, $0.31,0.42,0.52,0.65 \mathrm{inU} . \mathrm{V}(366 \mathrm{~nm})$ rays. $\mathrm{R}_{\mathrm{f}}$ values $0.15,0.23,0.24,0.25,0.52,0.61,0.86,0.91,0.98$. in Iodine Vapor.

Table:2. TLC Ethanol extract of rhizomes Vanya Haridra

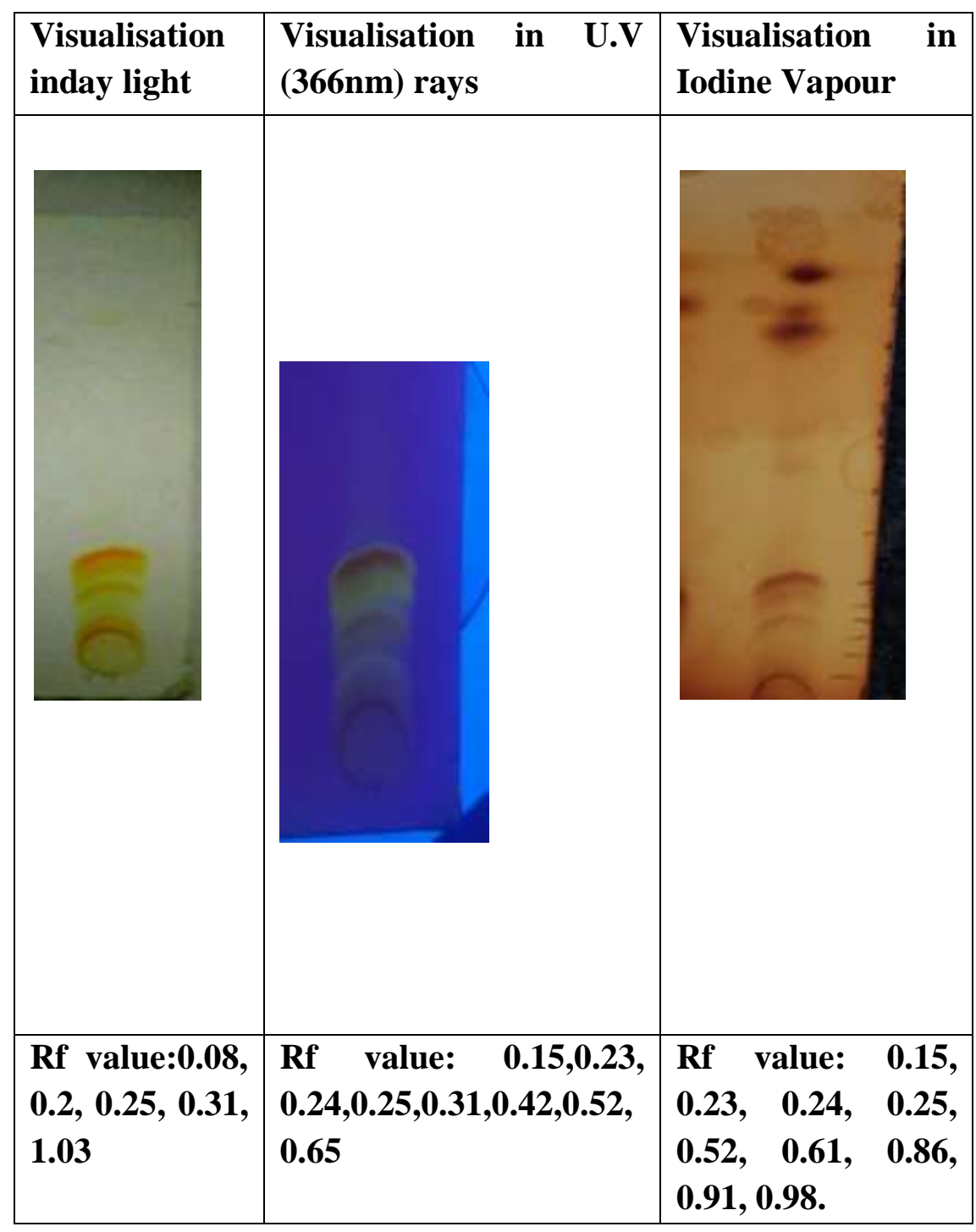

\section{Conclusion:}

The Phytochemical screening confirmed the presence of various phytochemical constituents such as Carbohydrates, Alkaloids, Amino acids, Saponin, Glycosides, Flavonoids, Steroids and Tannins. Different Physicochemical parameters such as Total Ash, Acid Insoluble Ash, Water Soluble Ash, Water soluble extract, Alcohol Soluble extract, Petroleum Ether extract and Loss on drying value was observed. These values can be useful to detect adulteration. All studied standardization parameters like Pharmacognostic study, Phytochemical screening and Physicochemical parameters provide the knowledge in the identification authentication of rhizome of Curcuma aromatica Salisb. 


\section{References:}

1. Bhavaprakasa Nighuntu.of Shri Bhavamisra commented by Padmshri Prof.K.C.Chunekar.Publishers C.Bharati Academy, Varanasi. Reprint - 2015.

2. Indian medicinal plants.illustrated, Vol-10. (By Kritikar \& Basu's) edited by K.S. Mhaskar, EBlalter, J.F.Cails, Third Revised, Pub-by-Sri satguru publication, A Division of Indian book centre 40/5, Shakti Nagar, Delhi-110007.

3. Dravyaguna Vigyana.Vol-1. Dr. Gyanendra Pandey, Pub- Chukhamba Krishnadas Academy Varanasi, ed-Third-2005.

4. Indian medicinal plants.illustrated, Vol-10. (By Kritikar \& Basu's) edited by K.S. Mhaskar, EBlalter, J.F.Cails, Third Revised, Pub-by-Sri satguru publication, A Division of Indian book centre 40/5, Shakti Nagar, Delhi-110007.

5. Dravyaguna Vigyana.Vol-1. Dr. Gyanendra Pandey, Pub- Chukhamba Krishnadas Academy Varanasi, ed-Third-2005.

6. Neerja P, Himanshu M, Jain DC. Phytochemical investigation of ethyl acetate extract from Curcuma aromatica Salisb. Rhizomes. Arabian Journal of Chemistry. 2013; 6:279-283.

7. Anjusha S, Gangaprasad A. Phytochemical and Antibacterial Analysis of Two Important Curcumaspecies, Curcuma aromatica Salisb.and Curcuma xanthorrhiza Roxb. (Zingiberaceae). Journal of Pharmacognosy and Phytochemistry. 2014; 3(3):50-53

8. CCRS,Laboratory guide for analysis of Ayurveda \& Sidha formulation.

9. CCRS,Laboratory guide for analysis of Ayurveda \& Sidha formulation.

10. CCRS,Laboratory guide for analysis of Ayurveda \& Sidha formulation.

11. CCRS,Laboratory guide for analysis of Ayurveda \& Sidha formulation.

12. CCRS,Laboratory guide for analysis of Ayurveda \& Sidha formulation. 